\title{
Protease-Activated Receptor 1 Contributes to Angiotensin II-Induced Cardiovascular Remodeling and Inflammation
}

\author{
Silvio Antoniak ${ }^{\mathrm{a}, \mathrm{b}}$ Jessica C. Cardenas ${ }^{\mathrm{b}}$ Laura J. Buczek $^{\mathrm{a}}$ Frank C. Church ${ }^{\mathrm{b}}$ \\ Nigel Mackman ${ }^{a}$ Rafal Pawlinski ${ }^{a}$ \\ ${ }^{a}$ UNC McAllister Heart Institute, Department of Medicine, and ${ }^{b}$ Department of Pathology and Laboratory Medicine, \\ University of North Carolina at Chapel Hill, Chapel Hill, NC, USA
}

\section{Keywords}

Protease-activated receptor 1 . Pre-hypertension .

Angiotensin $\cdot$ Heart failure $\cdot$ Fibrosis

\begin{abstract}
Background: Angiotensin II (Ang II) plays an important role in cardiovascular disease. It also leads to the activation of coagulation. The coagulation protease thrombin induces cellular responses by activating protease-activated receptor 1 (PAR-1). We investigated whether PAR-1 contributes to Ang II-induced cardiovascular remodeling and inflammation. Methods and Results: PAR $-1^{+/+}$(wild-type; WT) and PAR-1 ${ }^{-/-}$mice were infused with Ang II (600 ng/ $\left.\mathrm{kg} / \mathrm{min}\right)$ for up to 4 weeks. In WT mice, this dose of Ang II did not cause a significant increase in blood pressure but it did cause pathological changes in both the aorta and the heart. Ang II infusion resulted in vascular remodeling of the aorta, demonstrated by a significant increase in medial wall thickening and perivascular fibrosis. Importantly, both parameters were significantly attenuated by PAR-1 deficiency. Furthermore, perivascular fibrosis around coronary vessels was reduced in Ang II-treated PAR-1 ${ }^{-/}$mice compared to WT mice. In addition, PAR-1 deficiency significantly attenuated Ang II induction of inflammatory cytokines and profibrotic genes in the
\end{abstract}

\section{KARGER}

(c) 2016 S. Karger AG, Basel

E-Mail karger@karger.com

www.karger.com/crd aortas compared to WT mice. Finally, PAR-1 deficiency had no effect on Ang II-induced heart hypertrophy. However, the heart function measured by fractional shortening was less impaired in PAR-1 ${ }^{-/-}$mice than in WT mice. Conclusion: Our data indicate that PAR-1 plays a significant role in cardiovascular remodeling mediated by a blood pressure-independent action of Ang II.

(c) 2016 S. Karger AG, Basel

\section{Introduction}

The renin-angiotensin system (RAS) is a major contributor to the development and pathophysiology of hypertension (HTN) [1,2]. The major consequences of HTN are end-organ damage and cardiovascular complications [1, 2]. Angiotensin II (Ang II) is the main mediator of the RAS. Ang II is generated by enzymatic cleavage of angiotensinogen to Ang I by the protease renin, with subsequent conversion of Ang I to Ang II by angiotensinconverting enzyme $[1,2]$. In addition, chymase is the primary enzyme leading to this conversion in the heart [3]. Most of the effects of Ang II are mediated by angiotensin type $1\left(\mathrm{AT}_{1}\right)$ receptors $[1,2]$. While the human genome only contains one $\mathrm{AT}_{1}$ receptor, there are 2 subtypes 
$\left(\mathrm{AT}_{1 \mathrm{~A}}\right.$ and $\left.\mathrm{AT}_{1 \mathrm{~B}}\right)$ in mice $[4,5] . \mathrm{AT}_{1 \mathrm{~A}}$ appears to be the main receptor isoform regulating blood pressure (BP), whereas the specific function of $\mathrm{AT}_{1 \mathrm{~B}}$ is unclear [5]. $\mathrm{AT}_{1}$ receptors are widely distributed and Ang II-dependent activation of this receptor affects the function of virtually all organs, including the vasculature and heart $[1,2]$. Long-term exposure to Ang II leads to cardiovascular remodeling, fibrosis, and heart hypertrophy $[6,7]$. The mechanism of Ang II-induced heart remodeling may involve the direct action of Ang II on target tissues or be mediated by an Ang II-induced increase in BP $[1,2]$.

Ang II activation of the $\mathrm{AT}_{1}$ receptor also leads to upregulation of tissue factor (TF) expression. TF is the primary initiator of the coagulation cascade [8]. It is constitutively expressed in the blood vessel wall, as well as by cardiomyocytes and cardiac fibroblasts in the heart $[9,10]$. Several in vitro studies have demonstrated that Ang II induces TF expression in smooth-muscle cells, endothelial cells, and monocytes [7]. TF expression has also been found to be upregulated in the endothelium and media of blood vessels in hypertensive rats [11]. Moreover, blockage of the $\mathrm{AT}_{1}$ receptor with valsartan inhibits upregulation of TF expression [11]. Importantly, elevated levels of circulating TF have been observed in patients with HTN, and $\mathrm{AT}_{1}$ receptor blockage significantly reduces TF activity $[12,13]$. Recently, it was shown that Ang II infusion accelerates microvascular thrombosis in mice [14]. These data indicate that upregulation of TF expression during HTN is mediated via the $\mathrm{AT}_{1}$ receptor and may lead to systemic activation of the coagulation cascade.

Thrombin is the central protease of the coagulation cascade [15]. Human HTN patients and animal models of HTN have shown enhanced thrombin generation in plasma as measured by elevated thrombin-antithrombin (TAT) complexes $[16,17]$. In addition to its important role in both hemostasis and thrombosis, thrombin can induce multiple cellular responses via the activation of protease-activated receptors, such as protease-activated receptor 1 (PAR-1) [7, 15]. PAR-1 belongs to the family of 7 transmembrane domain $G$ protein-coupled receptors activated by proteolytic cleavage. PAR-1 is widely expressed within the vasculature and heart $[7,18,19]$. Studies by others and us have shown that PAR-1 plays a significant role in the physiology and pathophysiology of the cardiovascular system [7, 20-23]. Several ex vivo studies have documented that activation of PAR-1 induces endothelium-dependent relaxation in the aorta and coronary arteries [20, 22]. However, it has also been shown that activation of PAR-1 can elicit endothelium- or vascular smooth-muscle-dependent vasoconstriction [20,22].
These studies suggest that PAR-1-dependent vasoregulation may be cell/tissue specific. In mice, activation of PAR-1 with agonist peptide results in a biphasic BP response in which there is a rapid and transient hypotension followed by a sustained HTN, presumably via activation of PAR-1 on smooth-muscle cells [24]. Unstressed PAR- $1^{-/-}$mice exhibit no obvious abnormalities in baseline BP compared to PAR- $1^{+/+}$mice $[24,25]$.

In mouse and primate models of vascular injury, PAR1 expression is upregulated in proliferating neointima [26, 27]. PAR-1 deficiency resulted in protection against vascular remodeling and stenosis in an endothelial denudation model of vascular injury [26]. Inhibition of PAR-1 with an anti-PAR-1 antibody or selective PAR-1 antagonist RWJ-59259 in a balloon catheter injury model also reduced smooth-muscle cell proliferation and the intimal area and thickness, as well as the percentage of stenosis $[28,29]$. In vitro studies have demonstrated that activation of PAR-1 with either thrombin or agonist peptide leads to a series of molecular and morphological changes that result in hypertrophic growth of cardiomyocytes and proliferation of fibroblasts [30-32]. Recently, we showed that cardiomyocyte-specific overexpression of PAR-1 induced heart hypertrophy and decreased heart function via a TFdependent mechanism [23]. In addition, others and we have demonstrated that PAR-1 contributes to cardiac remodeling in different heart injury models $[7,23,33]$.

There are compelling data showing that Ang II leads to the activation of coagulation which might contribute to disease progression [7]. We therefore analyzed the contribution of PAR-1 signaling to Ang II-induced cardiac and vascular remodeling.

\section{Materials and Methods}

\section{Mice and Ang II Infusion}

PAR- $1^{+/-}$mice were backcrossed at least 11 generations onto a $\mathrm{C} 57 \mathrm{Bl} / 6 \mathrm{~J}$ background and bred to generate a PAR-1 $1^{-/-}$and PAR$1^{+/+}$littermate cousin line $[23,25,34]$. Male mice with an age between 8 and 12 weeks were used for all experiments. Mice were implanted with Alzet mini-osmotic pumps (Model 2004; DURECT Corporation) subcutaneously on the back of the neck. Infusion of Ang II (600 ng/kg/min; Sigma-Aldrich, St. Louis, MO, USA) was performed for up to 28 days. This study was approved by the Office of Animal Care and Use of the University of North Carolina at Chapel Hill and complied with National Institute of Health guidelines.

\section{Echocardiography and BP Measurements}

Heart function was analyzed by echocardiography in conscious mice using a VisualSonics Vevo2100 system (VisualSonics; Toronto, ON, Canada) as previously described [34, 35]. End systolic 
and diastolic LV volumes and LV wall dimensions were measured digitally on $\mathrm{M}$-mode tracings and averaged from at least 4 cardiac cycles. Fractional shortening was calculated from the measured LV dimensions [23]. BP were measured via the pressure-volume loop method with a 1.2-Fr admittance pressure-volume catheter (Sciscence, Ithaca, NY, USA) in anesthetized and ventilated mice as described elsewhere [36]. All measurements were done in UNC Rodent Advanced Surgical Models Core according to American Society of Echocardiography guidelines.

\section{Coagulation Parameters}

Blood was collected from the inferior vena cava into sodium citrate (final concentration $0.38 \%$ ) and plasma separated by centrifugation $\left(4,500 \mathrm{~g}, 15 \mathrm{~min}, 4^{\circ} \mathrm{C}\right)$. Levels of TATc in plasma were quantified by ELISA (TAT Enzygnost Micro Kit; Dade Behring/ Siemens) [34].

\section{Real-Time PCR}

Total mRNA from mouse hearts and aortas was isolated via the TriZol method $[35,37]$. One microgram of total mRNA was reverse transcribed into cDNA and analyzed by real-time PCR using RealMasterMix and RealPlex ${ }^{2}$ MasterCycler (Eppendorf AG, Hamburg, Germany) [38]. To analyze the expression of interleukin (IL)-1 $\beta$, CXCL1, CXCL2, transforming growth factor (TGF)$\beta 1$, TGF- $\beta 3$, connective tissue growth factor (CTGF), collagen (Coll) IaI, Coll Ia2, and Coll 3 mRNA we used predesigned probe sets (Integrated DNA Technologies, Coralville, IA, USA). Variations in loading were adjusted using hypoxanthine-guanine phosphoribosyltransferase mRNA expression.

\section{Histology}

Fibrosis and cellular infiltration were visualized on formalinfixed, paraffin-embedded heart and aorta sections stained with Masson's trichrome and H\&E, respectively [10, 35, 38]. Stained tissue sections were subsequently viewed using an Olympus BX51 microscope (Tokyo, Japan) and photographed using an Olympus DP70 digital camera with a DP controller and DP manager computer software $[34,35,38]$.

\section{Statistical Analysis}

All statistical analyses were performed using GraphPad Prism (version 5.04; GraphPad Software Inc., La Jolla, CA, USA). Data are presented as means \pm SEM. For 2-group comparisons of continuous data, a 2-tailed Student's $t$ test was used. For multiplegroup comparisons, normally distributed data were analyzed by 1- or 2-way ANOVA and Bonferroni corrected for repeated measures over time. $p \leq 0.05$ was considered statistically significant.

\section{Results}

Infusion of Ang II Leads to Systemic Activation of Coagulation and Heart Hypertrophy Associated with Cardiac Fibrosis and Inflammation

To determine whether chronic $\mathrm{AT}_{1}$ receptor stimulation leads to cardiovascular remodeling and inflammation as well as activation of coagulation, wild-type (WT) mice were infused for up to 14 days with Ang II (600 ng/ $\mathrm{kg} / \mathrm{min}$ ). As expected, $\mathrm{AT}_{1}$ receptor stimulation in $\mathrm{WT}$ mice led to a significant increase in heart weight:body weight (HW:BW) ratios after 14 days of Ang II infusion (Fig. 1a). Importantly, we also observed a systemic activation of coagulation measured by plasma TATc levels on day 14 after pump installation (Fig. 1a). The increased heart hypertrophy and procoagulant state were associated with interstitial and perivascular fibrosis within the heart muscle (Fig. 1b) and increased cellular infiltrations (Fig. 1c) after 7 days of Ang II infusion. Our observation suggests that chronic activation of the $\mathrm{AT}_{1}$ receptor leads to activation of coagulation which was associated with pathologic cardiac fibrosis, inflammation, and remodeling.

\section{PAR-1 Deficiency Has No Effect on BP before and after Ang II Infusion}

To determine whether PAR-1 activation contributes to basal and Ang II-dependent BP, the BP in WT and PAR-1-deficient mice was measured before and 7 and 28 days after constant Ang II infusion. Consistent with previously published data, PAR-1 deficiency had no significant effect on the baseline diastolic and systolic BP (see online suppl. Fig. 1; for all online suppl. material, see www.karger.com/doi/10.1159/000452269) [24, 25]. Interestingly, infusion of Ang II at a concentration of 600 $\mathrm{ng} / \mathrm{kg} / \mathrm{min}$ caused only a modest but not statistically significant increase in BP in both WT and PAR-1 ${ }^{-1-}$ mice, measured on days 7 and 28 after initiation of the infusion (see online suppl. Fig. 1). In addition, we did not find any differences between genotypes with regard to $\mathrm{BP}$ on days 7 and 28. This suggests that PAR-1 does not play a major role in baseline $\mathrm{BP}$ regulation and that the all of the observations in our study were due to $\mathrm{BP}$-independent $\mathrm{AT}_{1^{-}}$ and PAR-1-mediated signaling events in the setting resembling pre-HTN conditions [39].

\section{PAR-1 Deficiency Attenuates Ang II-Induced Remodeling of the Aorta}

Ang II infusion in mice is known to lead to vascular remodeling in the aorta, associated with increased media thickness and enhanced fibrosis [6]. To determine whether PAR-1 affects these parameters, media-to-lumen and fibrosis-to-lumen ratios of aortas were analyzed before and 28 days after Ang II infusion in WT and PAR-1-deficient mice. There were no significant differences with regard to aorta media thickness or the amount of fibrotic tissue around the aorta in mice of both genotypes before Ang II infusion (Fig. 2). As expected, chronic $\mathrm{AT}_{1}$ stimu- 
Fig. 1. Infusion of angiotensin (Ang II) leads to cardiac hypertrophy, systemic activation of coagulation associated with cardiac fibrosis and inflammation. a Increase in heart weight to body weight (HW:BW) ratios and plasma levels of thrombin-antithrombin complexes (TAT) in Ang IItreated wild-type mice. Data (means \pm SEM; $n=3$ for each time point) were analyzed using Student's $t$ test. Statistical significance is shown as * $p<0.05$. b Masson's trichrome staining of representative heart sections from controls (left) and mice treated with Ang II for 7 days (middle and right). c Inflammatory cells are present in $\mathrm{H} \& \mathrm{E}$-stained heart sections from Ang IItreated mice (right) but not from control mice (left). Scale bars, $200 \mu \mathrm{m}$.

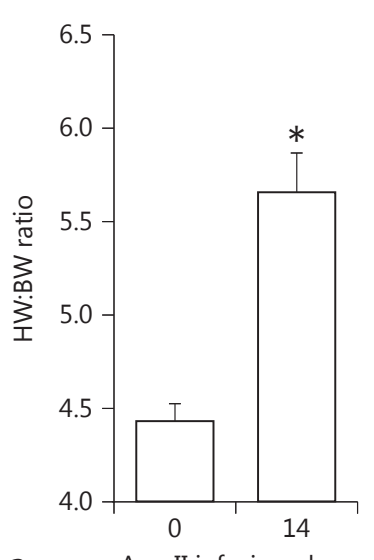

a Ang II infusion, days

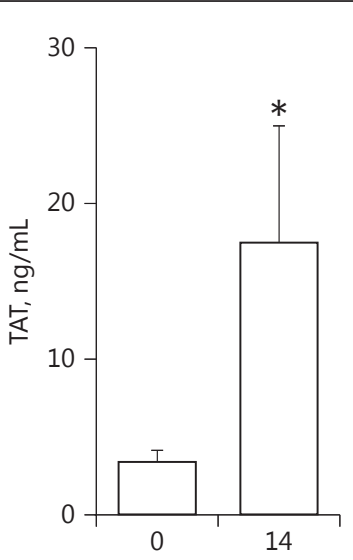

Ang II infusion, days
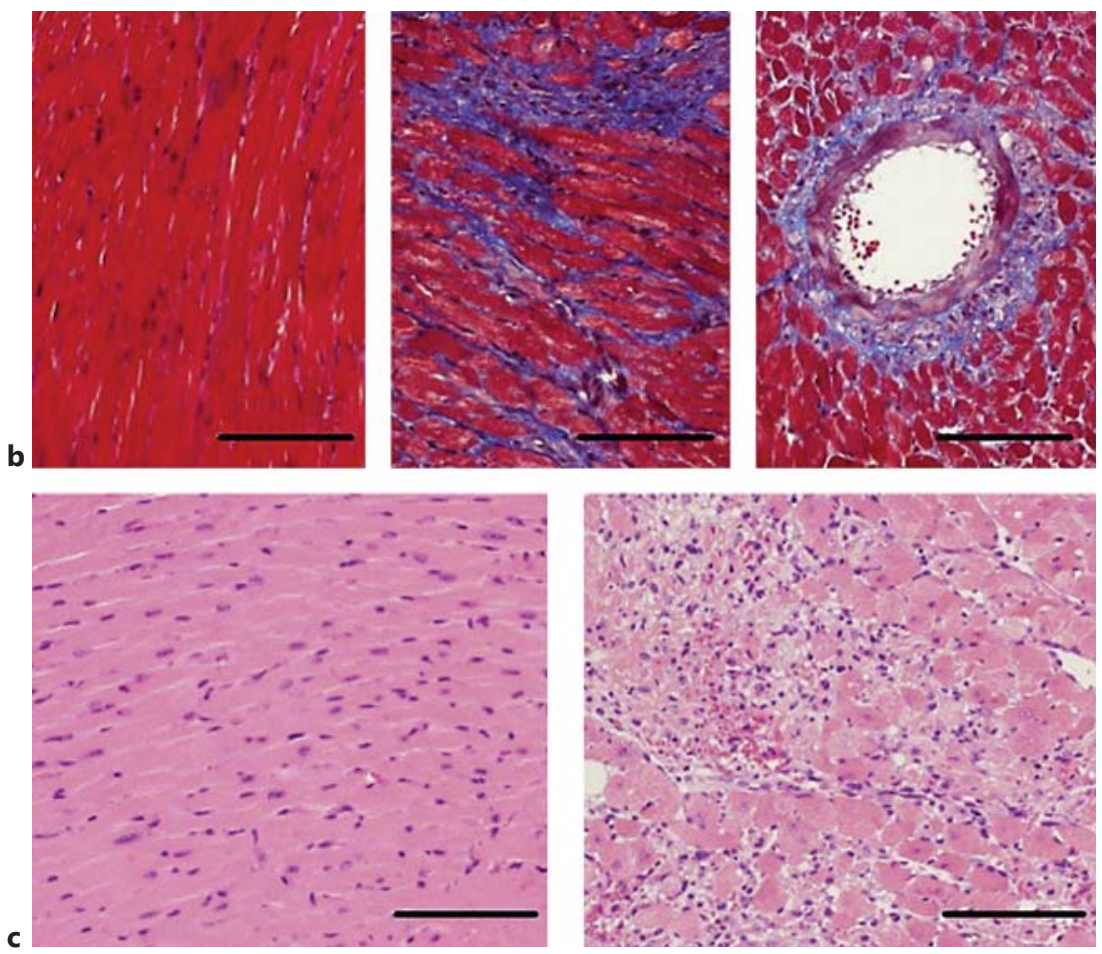

Reduced Expression of Inflammatory and Profibrotic Markers in the Aortas of PAR-1-Deficient Mice

To determine whether changes in vascular remodeling induced by Ang II are associated with changes in the expression profile of inflammatory and profibrotic genes in the aorta, real-time PCR was performed on aorta samples of WT and PAR-1-deficient mice before and 7 and 28 days after Ang II infusion. Importantly, there were no significant differences between genotypes in baseline mRNA expression levels in the aorta of the inflammatory media- 
Fig. 2. Protease-activated receptor 1 (PAR1) deficiency attenuates angiotensin II (Ang II)-induced remodeling of the aorta. a Representative cross-sections of thoracic parts of aortas stained with Masson's trichrome. Scale bars, $1 \mathrm{~mm}$. Quantification of the media area:lumen area (b) and fibrotic area:lumen area (c) ratios from PAR- $1^{+/+}$(white bars) and PAR-1 ${ }^{-/-}$(gray bars) mouse aortas before and 28 days after constant Ang II infusion. Data (means \pm SEM; $n=5$ for day 0 and $n=10$ for day 28) were analyzed by 2 -way ANOVA. Statistical significance is shown as ${ }^{\#} p<0.05$ and ${ }^{*} p<0.05$ vs. day 0 of the respective genotype.
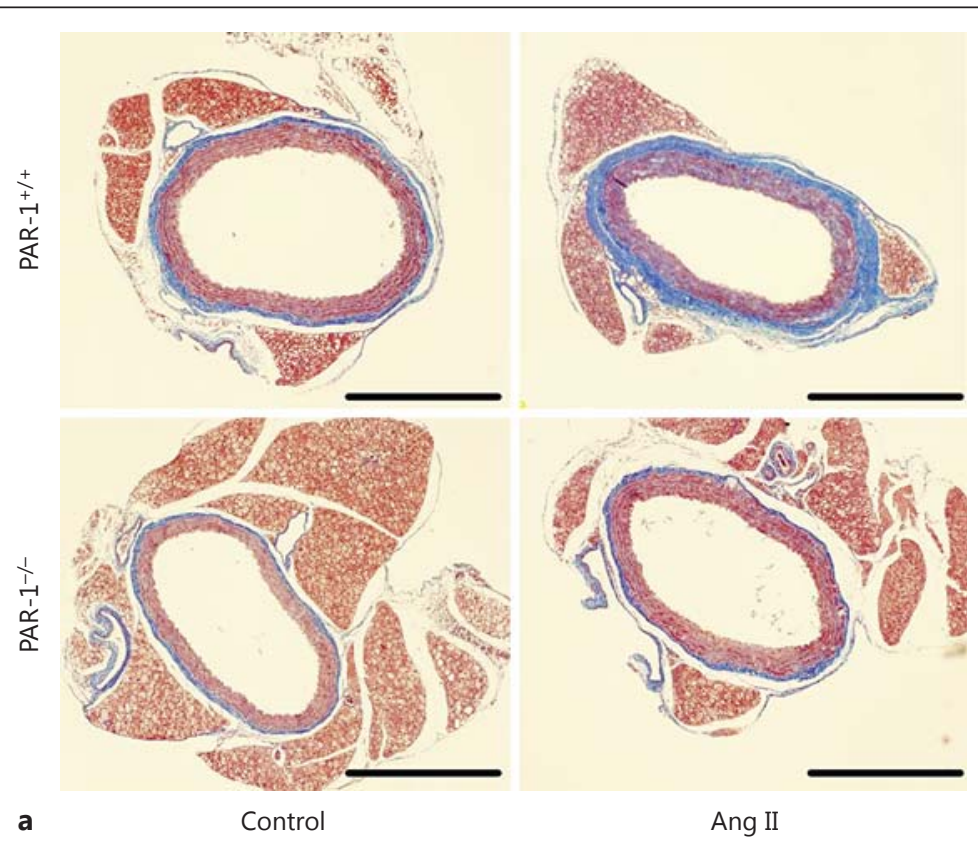

tors IL-1 $\beta$, IL-6, TNF- $\alpha$, MCP-1, CXCL1, and CXCL2 or the profibrotic mediators TGF- $\beta 1$, TGF- $\beta 3$, and CTGF or the extracellular matrix components Coll Ia1, Coll Ia2, and Coll III (Fig. 3 and data not shown). Except for CTGF, Ang II infusion led to a significant increase in the mRNA expression of all measured genes in WT mice at 7 days. Later, on day 28, the aortic expression levels of the analyzed genes in WT mice returned to baseline, with the exception of CTGF (Fig. 3f). Importantly, PAR-1 deficiency was associated with less proinflammatory and pro- 

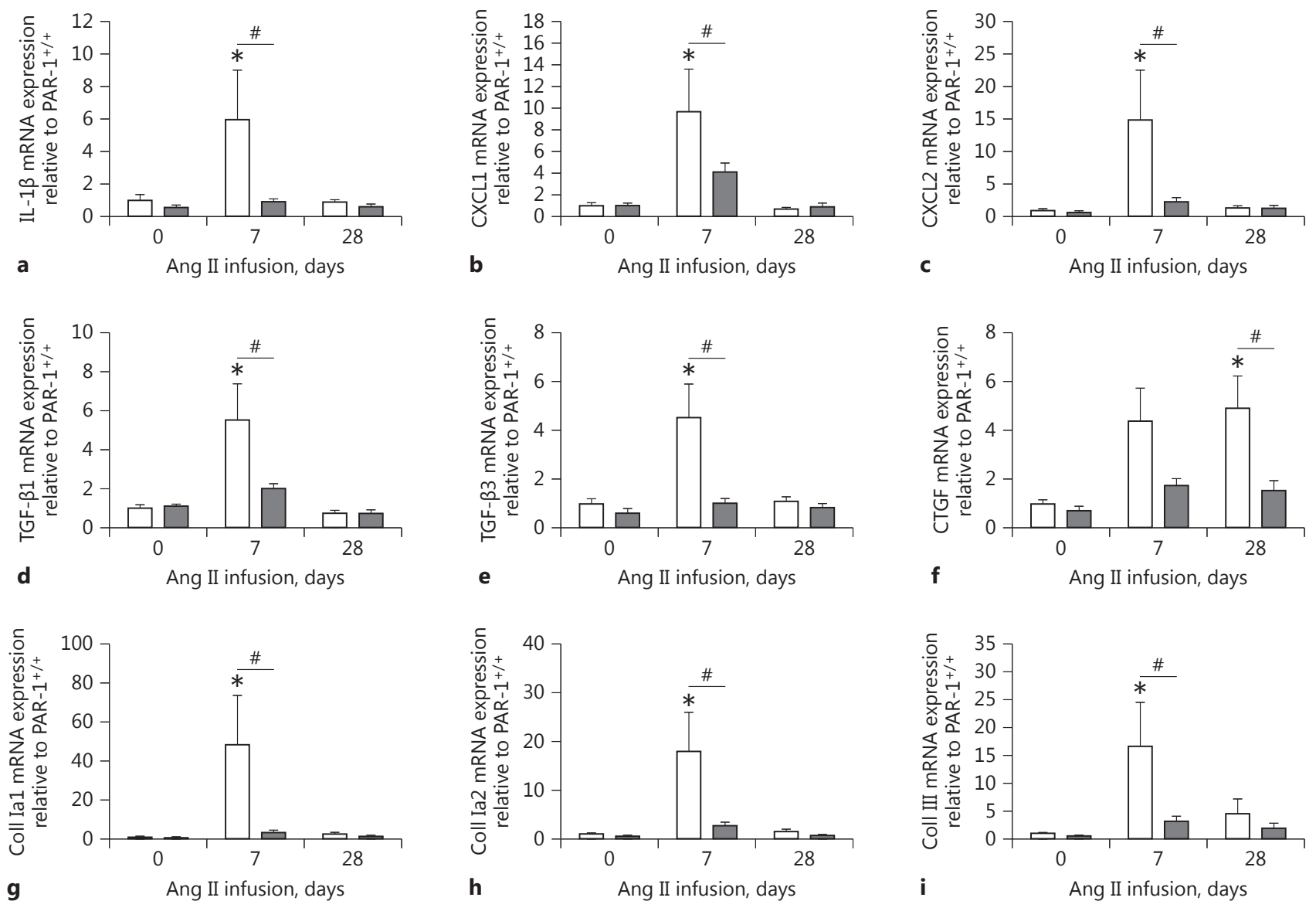

Fig. 3. Reduced expression of inflammatory and profibrotic markers in the aortas of protease-activated receptor 1 (PAR-1)-deficient mice. Real-time PCR analysis of mRNA expression of the inflammatory mediators interleukin (IL)-1 $\beta$ (a), CXCL1 (KC) (b), and CXCL2 (inflammatory protein 2- $\alpha$; MIP-2 $\alpha$ ) (c) and the profibrotic markers transforming growth factor (TGF)- $\beta 1$ (d), TGF- $\beta 3$ (e), and connective tissue growth factor (CTGF) (f), as well as the ex-

fibrotic gene expression compared to day 7 , as well as CTGF on day 28 (Fig. 3). These data indicate that PAR-1 is involved in regulation of a transient proinflammatory and profibrotic phenotype leading to vascular inflammation and remodeling in the aorta during chronic Ang II infusion.

\section{Ang II-Induced Perivascular Fibrosis of Coronary Arteries Is Reduced in Ang II-Treated \\ PAR-1-Deficient Mice}

Besides its effect on the aorta, Ang II leads to perivascular fibrosis of coronary vessels and heart hypertrophy tracellular matrix proteins collagen (Coll) Ia1 (g), Coll Ia2 (h), and Coll III (i) in the aortas of PAR-1 $1^{+/+}$(white bars) and PAR-1 $1^{-/-}$ (gray bars) mice before and after 7 and 28 days of constant Ang II infusion. Data (means \pm SEM; $n=6-10$ ) were analyzed by 2 -way ANOVA. Statistical significance is shown as ${ }^{\#} p<0.05$ and ${ }^{*} p<$ 0.05 vs. day 0 of the respective genotype.

[6]. To analyze Ang II-dependent changes in perivascular fibrosis and cardiac remodeling, hearts of WT and PAR1-deficient mice were analyzed before and 7 and 28 days after Ang II infusion. We did not observe any differences in the level of perivascular fibrosis around the cardiac arteries before Ang II infusion, measured based on the fibrosis area:lumen area ratio (Fig. $4 \mathrm{a}, \mathrm{b}$ ). Chronic $\mathrm{AT}_{1}$ stimulation led to an increase in perivascular fibrosis around the coronary arteries in both WT and PAR-1-deficient mice, visualized by Masson's trichrome staining of heart sections (Fig. 4a). However, this parameter was significantly increased only in WT but not in PAR- $1^{-/-}$mice 
Fig. 4. Protease-activated receptor 1 (PAR-1)-deficient mice are protected against angiotensin II (Ang II)-induced cardiac fibrosis and heart dysfunction. a Representative sections of heart coronary vessels from PAR $-1^{+/+}$and PAR- $1^{-/-}$mice after 28 days of constant Ang II infusion stained with Masson's trichrome. Scale bars, $200 \mu \mathrm{m}$. b Quantification of the fibrotic area:lumen area ratio of heart coronary vessels from PAR $-1^{+/+}$(white bars) and PAR-1 $1^{-/-}$(gray bars) mice before and after 28 days of constant Ang II infusion. c Real-time PCR analysis of connective tissue growth factor (CTGF) mRNA expression in the hearts of PAR $-1^{+/+}$and PAR $-1^{-1-}$ mice before and after 7 and 28 days of continuous Ang II infusion. Heart weight:body weight ratios (HW:BW) (d) and fractional shortening (e) measured by echocardiography before and after 28 days of Ang II infusion. Data (means \pm SEM; $n=6-10$ ) were analyzed by 2 -way ANOVA. Statistical significance is shown as ${ }^{\#} p<0.05$ and $* p<0.05$ vs. day 0 of the respective genotype.

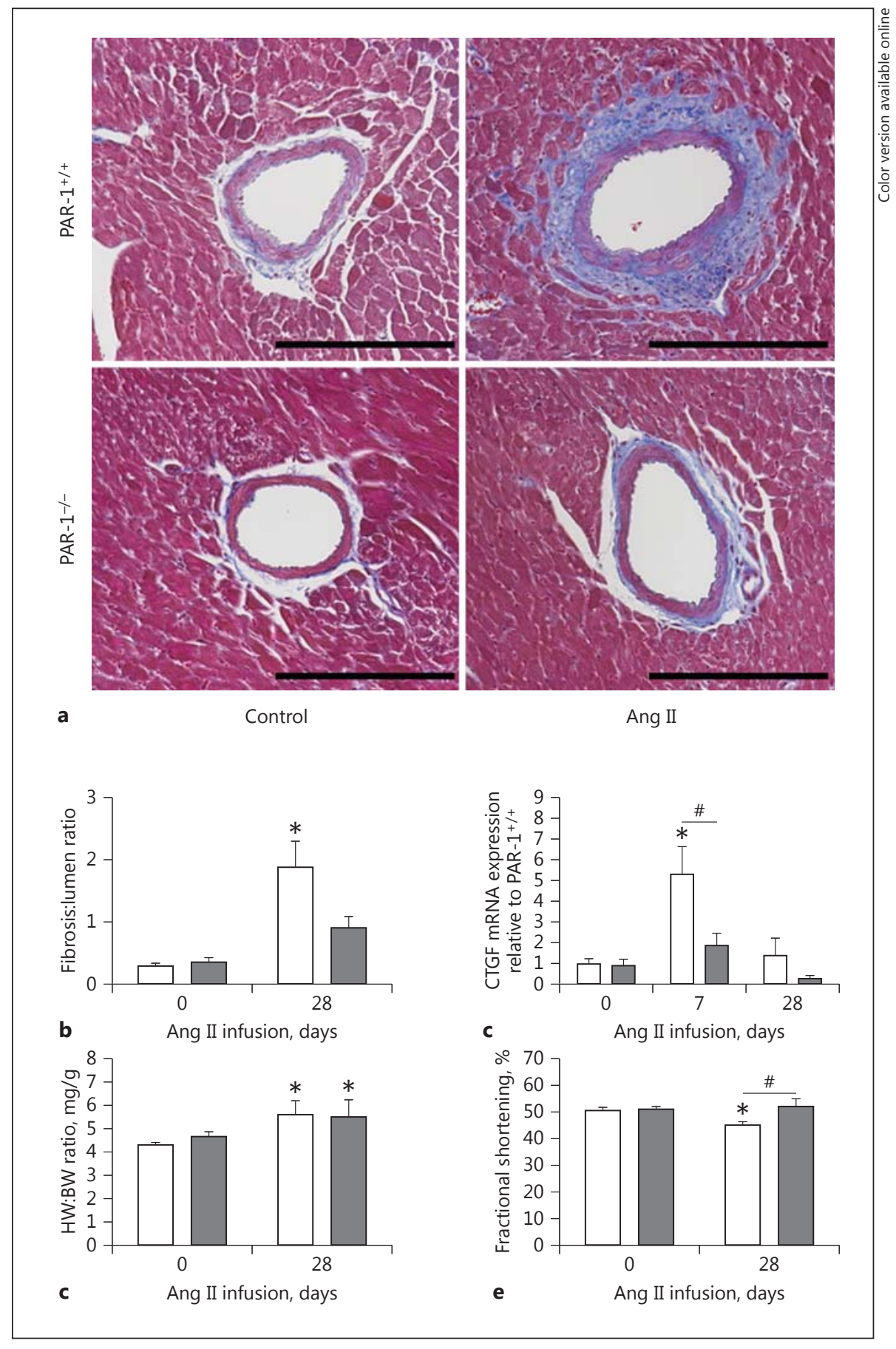

on day 28 (Fig. 4b). Next, we analyzed the expression of CTGF in the heart, which was shown to be associated with pathologic cardiac fibrosis and remodeling [38]. CTGF expression was significantly increased in the hearts of WT mice 7 days after Ang II infusion and returned to baseline (Fig. 4c) on day 28. Importantly, 7 days after Ang II infusion, CTGF mRNA expression was significantly lower in the hearts of PAR-1-deficient mice compared to WT controls (Fig. 4c).

\section{PAR-1-Deficient Mice Are Protected against \\ Ang II-Induced Heart Dysfunction}

Chronic $\mathrm{AT}_{1}$ stimulation is known to induce heart hypertrophy leading to heart dysfunction [40]. To analyze 
changes in heart hypertrophy, HW:BW ratios were calculated in WT and PAR-1-deficient mice before and 28 days after Ang II infusion. PAR-1 deficiency did not affect this parameter at baseline (Fig. 4d). HW:BW ratios were significantly increased 28 days after Ang II infusion. However, PAR-1 deficiency did not affect heart hypertrophy. Despite that, PAR-1-deficient mice had a better preserved heart function compared to WT mice 28 days after Ang II infusion (Fig. 4e). This observation suggests that a lack of PAR-1-dependent signaling protects against Ang IIinduced heart dysfunction independently of heart hypertrophy.

\section{Discussion}

In this study, we demonstrated that PAR-1 deficiency attenuates pathologic Ang II-induced remodeling of the cardiovascular system. PAR-1 deficiency was associated with a reduced mRNA expression of proinflammatory and profibrotic markers, which correlated with attenuation of fibrosis and remodeling in the aortas of Ang IItreated mice. In addition, we also observed reduced perivascular fibrosis of coronary vessels in the hearts of PAR1-deficient mice after Ang II treatment. The reduced cardiac fibrosis in PAR-1-deficient mice led to a preserved heart function compared to Ang II-treated WT mice. Interestingly, our observation was independent of a change in $\mathrm{BP}$ as well as heart hypertrophy since PAR-1 deficiency had no effect on these parameters. Our data indicate that PAR-1 plays a significant role in cardiovascular remodeling mediated by the $\mathrm{BP}$-independent action of Ang II.

In our study, we were not able to detect increased BP in anesthetized mice after $600 \mathrm{ng} / \mathrm{kg} / \mathrm{min}$ Ang II infusion. This was surprising since even a lower Ang II dose (490 $\mathrm{ng} / \mathrm{kg} / \mathrm{min}$ ) was shown to increase BP in telemetric observed animals [41]. However, the BP discrepancy might be due to the measurement used. Anesthesia has cardiodepressive effects leading to hypotension, which might have masked the real BP elevation in our experimental mice [42]. Thus, our study mimicked a murine pre-HTN model with BP below levels defined as HTN. Pre-HTN is described as BP between 120 and $139 \mathrm{~mm} \mathrm{Hg}$ systolic or 80 and $89 \mathrm{~mm} \mathrm{Hg}$ diastolic [39]. It is thought that a preHTN status adds a moderate-to-high risk to the total cardiovascular risk [39]. Importantly, the Framingham Heart Study showed that patients with pre-HTN have an increased risk of developing HTN [43]. Furthermore, the ATTICA study reported an association between pre-
HTN and increased inflammation, which was linked to the atherosclerotic process [39]. It was concluded that increased inflammation might be a mechanism in the initiation and/or progression of pre-HTN $[44,45]$.

The ongoing inflammation might be mediated by both innate and adaptive immune processes. The innate immune pathway not only responds to exogenous pathogens but can be also activated by damage-associated molecular patterns released endogenous by stressed, damaged, or necrotic cells [46]. Damage-associated molecular patterns are present in cardiovascular diseases during HTN [47]. AT $_{1}$ activation has been shown to induce p53dependent apoptosis of cultured rat cardiomyocytes, which might lead the release of damage-associated molecular patterns [48]. Interestingly, Singh et al. [49] reported that Ang II-mediated cardiac hypertrophy and proinflammatory gene expression were mainly caused by TRIF pathway activation. Those authors further showed that the expression of the TRIF-dependent cytokine CXCL10 was increased in MyD88 ${ }^{-/-}$mouse hearts but reduced in mice lacking TRIF signaling [49]. We found that PAR-1 stimulation enhanced Toll-like receptor (TLR)-3/ TRIF-dependent CXCL10 expression in cardiac fibroblasts and immune cells $[34,37]$. This suggests that PAR1 possibly enhanced pathologic TRIF signaling during Ang II infusion. Besides its effect on TLR signaling, PAR1 activation induces the classic hallmarks of inflammation, including enhanced vascular permeability and upregulation of proinflammatory mediators and adhesion molecules [21]. In our study, we observed a PAR-1-dependent proinflammatory state in mice after Ang II infusion measured by increased IL- $1 \beta$, IL- 6 , TNF- $\alpha$, MCP-1, CXCL1, and CXCL2 expression in the aorta. Consistent with this observation, a study showed that increased plasma levels of IL- $1 \beta$, a cytokine involved in monocyte activation, precede changes in BP in HTN [50]. Furthermore, IL-6, MCP-1, and especially TNF- $\alpha$, have been shown to be essential for the pathologic effects of Ang II on the vasculature by increasing oxidative stress, activating fibroblasts, and attracting $\mathrm{T}$ cells $[47,51]$.

Expression of proinflammatory cytokines is further linked to induction of a profibrotic phenotype. In addition, a mild-to-moderate increase in BP has been reported to stimulate fibroblasts and increase Coll formation leading to fibrotic remodeling of the myocardium with a normal LV mass [52]. TGF- $\beta 1 \mathrm{mRNA}$ and protein expression are increased in HTN patients [53]. CTGF has a role as a downstream mediator of the chronic fibrotic effects of TGF- $\beta$. Activated TGF- $\beta$ induces CTGF expression in fibroblasts and cardiomyocytes [54]. During this 
process fibroblasts differentiate into myofibroblasts, the major cells that synthesize Coll in cardiac remodeling [55, 56]. Activation of PAR-1 on fibroblasts induced cell proliferation and expression of profibrotic genes $[32,57]$. Here, we found increased expression of CTGF and TGF- $\beta$, as well as Coll, in Ang II-infused WT mice but not in PAR-1 ${ }^{-/-}$mice. This PAR-1-dependent profibrotic phenotype resulted in increased vascular and perivascular remodeling associated with fibrosis and a possible reduced elasticity of the aorta and coronary arteries. This is consistent with the finding of Celik et al. $[44,58]$ that preHTN was associated with impairment of aortic elasticity and inflammation compared to healthy controls. These changes may lead to a reduced coronary flow very early in pre-HTN before hypertrophy is apparent and thus may cause subsequent ischemia and fibrosis $[59,60]$. Structural abnormalities are already seen in pre-HTN patients, though in a milder manner compared to newly diagnosed HTN patients, which might lead to cardiac remodeling $[33,61]$. In our study, we did not observe any differences in cardiac hypertrophy between the two genotypes. This was surprising since others and we have shown that PAR1 contributes to cardiomyocyte hypertrophy and cardiac remodeling $[23,30]$. However, the significant differences in fibrosis independently of hypertrophy might be due to the AT receptor distribution on cardiac fibroblasts and cardiomyocytes. Cardiomyocytes express comparable amounts of $\mathrm{AT}_{1}$ and $\mathrm{AT}_{2}$ receptors, whereas fibroblasts express predominantly $\mathrm{AT}_{1}$ [62]. In addition, $\mathrm{AT}_{2}$ has been shown to counteract $\mathrm{AT}_{1}$ activation [62]. Importantly, increased vascular inflammation, as well as arterial stiffness, has been shown to be predictive of cardiovascular events [63, 64].

The remaining topic for further studies is the physiologic activator of PAR-1 in the setting of chronic Ang II infusion, $\mathrm{AT}_{1}$ stimulation, and HTN. The most likely candidate is thrombin. In our study, we observed increased TAT levels after chronic Ang II infusion. Consistent with our findings, it has been shown that $\mathrm{AT}_{1}$ receptor stimulation and HTN are linked to increased activation of coagulation due to increased TF expression and thrombin generation $[11-13,16,17]$, which lead to a prothrombotic phenotype [14]. Another possible activator is the noncanonical activation of PAR-1 by matrix-metalloproteinases (MMP)-1 or MMP-13 [7]. Recently, it was shown that MMP-1 enhanced Ang II-induced vasoconstriction in endothelium-intact omental arteries in a PAR-1-dependent way ex vivo [65]. Furthermore, MMP-13 is expressed and active during Ang II-induced HTN [66]. We showed that the MMP-13/PAR-1 pathways is active in cardiovascular disease models [7, 18, 33, 34].

Importantly, besides its proven pathologic role, TF expressed by extravascular cells in the brain, lung, and heart, such as astrocytes, epithelial cells, smooth-muscle cells, fibroblasts, and cardiomyocytes maintains organ hemostasis [10, 11, 23, 67-71]. Reduced TF-dependent initiation of coagulation can result in hemorrhages, increased tissue fibrosis, and a reduced overall survival under healthy as well as pathologic conditions $[10,68,71]$. This dual role makes is difficult to use TF blockage as a viable therapy option [70]. Based on our data, further studies are warranted to investigate the effect of the PAR-1 inhibitor vorapaxar in Ang II-induced cardiovascular remodeling.

\section{Conclusion}

Taken together, our data suggest that the PAR-1 signaling pathway contributes to Ang II-induced cardiac fibrosis and heart dysfunction.

\section{Acknowledgment}

We thank Ying Zhang and Wyeth Alexander for their excellent technical assistance, and Drs. Michael F. Bode and Tracy Stokol for their helpful comments. This study was supported by grants from the American Heart Association to S.A. (14BGIA20380134) and R.P. (09BGIA2150078), and from the National Institute of Health to R.P. (RO1 HL096679).

\section{Conflict of Interest}

There are no financial interests.

\section{References}

Antoniak/Cardenas/Buczek/Church/ Mackman/Pawlinski
1 Mehta PK, Griendling KK: Angiotensin II cell signaling: physiological and pathological effects in the cardiovascular system. Am J Physiol Cell Physiol 2007;292:C82-C97.

2 Marchesi C, Paradis P, Schiffrin EL: Role of the renin-angiotensin system in vascular inflammation. Trends Pharmacol Sci 2008;29: 367-374.

3 Wolny A, Clozel JP, Rein J, Mory P, Vogt P, Turino M, Kiowski W, Fischli W: Functional and biochemical analysis of angiotensin IIforming pathways in the human heart. Circ Res 1997;80:219-227. 
4 Sasamura H, Hein L, Krieger JE, Pratt RE, Kobilka BK, Dzau VJ: Cloning, characterization, and expression of two angiotensin receptor (AT-1) isoforms from the mouse genome. Biochem Biophys Res Commun 1992; 185: 253-259.

5 Kato H, Ishida J, Matsusaka T, Ishimaru T, Tanimoto K, Sugiyama F, Yagami K, Nangaku M, Fukamizu A: Erythropoiesis and blood pressure are regulated via AT1 receptor by distinctive pathways. PLoS One 2015; 10:e0129484.

6 Takayanagi T, Kawai T, Forrester SJ, Obama T, Tsuji T, Fukuda Y, Elliott KJ, Tilley DG, Davisson RL, Park JY, Eguchi S: Role of epidermal growth factor receptor and endoplasmic reticulum stress in vascular remodeling induced by angiotensin II. Hypertension 2015;65:1349-1355.

7 Antoniak S, Sparkenbaugh E, Pawlinski R: Tissue factor, protease activated receptors and pathologic heart remodelling. Thromb Haemost 2014;112:893-900.

8 Pawlinski R, Pedersen B, Erlich J, Mackman $\mathrm{N}$ : Role of tissue factor in haemostasis, thrombosis, angiogenesis and inflammation: lessons from low tissue factor mice. Thromb Haemost 2004;92:444-450.

9 Mackman N, Tilley RE, Key NS: Role of the extrinsic pathway of blood coagulation in hemostasis and thrombosis. Arterioscler Thromb Vasc Biol 2007;27:1687-1693.

10 Pawlinski R, Tencati M, Holscher T, Pedersen B, Voet T, Tilley RE, Marynen P, Mackman N: Role of cardiac myocyte tissue factor in heart hemostasis. J Thromb Haemost 2007;5:16931700.

11 Muller DN, Mervaala EM, Dechend R, Fiebeler A, Park JK, Schmidt F, Theuer J, Breu V, Mackman N, Luther T, Schneider W, Gulba D, Ganten D, Haller H, Luft FC: Angiotensin II (AT(1)) receptor blockade reduces vascular tissue factor in angiotensin II-induced cardiac vasculopathy. Am J Pathol 2000;157:111-122.

12 Koh KK, Chung WJ, Ahn JY, Han SH, Kang WC, Seo YH, Ahn TH, Choi IS, Shin EK: Angiotensin II type 1 receptor blockers reduce tissue factor activity and plasminogen activator inhibitor type-1 antigen in hypertensive patients: a randomized, double-blind, placebo-controlled study. Atherosclerosis 2004; 177:155-160.

13 Steffel J, Luscher TF, Tanner FC: Tissue factor in cardiovascular diseases: molecular mechanisms and clinical implications. Circulation 2006;113:722-731.

14 Senchenkova EY, Russell J, Esmon CT, Granger DN: Roles of coagulation and fibrinolysis in angiotensin II-enhanced microvascular thrombosis. Microcirculation 2014;21: 401-407.

15 Coughlin SR: Thrombin signalling and protease-activated receptors. Nature 2000;407: 258-264.
16 Ekholm M, Wallen $\mathrm{NH}$, Johnsson $\mathrm{H}$, Eliasson $\mathrm{K}$, Kahan T: Long-term angiotensin-converting enzyme inhibition with ramipril reduces thrombin generation in human hypertension. Clin Sci (Lond) 2002;103:151-155.

17 Sawada K, Naiki M, Yago H, Matsushita K, Ohtsuki T, Kitagawa K, Matsumoto M, Hori M: Hypertension associated with reduced plasma thrombomodulin levels and a hypercoagulable state in rats. Clin Exp Hypertens 2003;25:73-84.

18 Antoniak S, Mackman N: Coagulation, protease-activated receptors, and viral myocarditis. J Cardiovasc Transl Res 2014;7:203-211.

19 Antoniak S, Pawlinski R, Mackman N: Protease-activated receptors and myocardial infarction. IUBMB Life 2011;63:383-389.

20 Leger AJ, Covic L, Kuliopulos A: Protease-activated receptors in cardiovascular diseases. Circulation 2006;114:1070-1077.

21 Major CD, Santulli RJ, Derian CK, AndradeGordon P: Extracellular mediators in atherosclerosis and thrombosis: lessons from thrombin receptor knockout mice. Arterioscler Thromb Vasc Biol 2003;23:931-939.

22 Steinberg SF: The cardiovascular actions of protease-activated receptors. Mol Pharmacol 2005;67:2-11.

23 Pawlinski R, Tencati M, Hampton CR, Shishido T, Bullard TA, Casey LM, Andrade-Gordon P, Kotzsch M, Spring D, Luther T, Abe J, Pohlman TH, Verrier ED, Blaxall BC, Mackman N: Protease-activated receptor-1 contributes to cardiac remodeling and hypertrophy. Circulation 2007;116:2298-2306.

24 Cheung WM, Andrade-Gordon P, Derian CK, Damiano BP: Receptor-activating peptides distinguish thrombin receptor (PAR-1) and protease activated receptor 2 (PAR-2) mediated hemodynamic responses in vivo. Can J Physiol Pharmacol 1998;76:16-25.

25 Darrow AL, Fung-Leung WP, Ye RD, Santulli RJ, Cheung WM, Derian CK, Burns CL, Damiano BP, Zhou L, Keenan CM, Peterson PA, Andrade-Gordon P: Biological consequences of thrombin receptor deficiency in mice. Thromb Haemost 1996;76:860-866.

26 Cheung WM, D'Andrea MR, Andrade-Gordon P, Damiano BP: Altered vascular injury responses in mice deficient in protease-activated receptor-1. Arterioscler Thromb Vasc Biol 1999;19:3014-3024.

27 Wilcox JN, Rodriguez J, Subramanian R, Ollerenshaw J, Zhong C, Hayzer DJ, Horaist C, Hanson SR, Lumsden A, Salam TA, et al: Characterization of thrombin receptor expression during vascular lesion formation. Circ Res 1994;75:1029-1038.

28 Takada M, Tanaka H, Yamada T, Ito O, Kogushi M, Yanagimachi M, Kawamura T, Musha T, Yoshida F, Ito M, Kobayashi H, Yoshitake S, Saito I: Antibody to thrombin receptor inhibits neointimal smooth muscle cell accumulation without causing inhibition of platelet aggregation or altering hemostatic parameters after angioplasty in rat. Circ Res 1998;82. 980-987.
29 Andrade-Gordon P, Derian CK, Maryanoff BE, Zhang HC, Addo MF, Cheung W, Damiano BP, D'Andrea MR, Darrow AL, de Garavilla L, Eckardt AJ, Giardino EC, Haertlein BJ, McComsey DF: Administration of a potent antagonist of protease-activated receptor-1 (PAR-1) attenuates vascular restenosis following balloon angioplasty in rats. J Pharmacol Exp Ther 2001;298:34-42.

30 Sabri A, Muske G, Zhang H, Pak E, Darrow A, Andrade-Gordon P, Steinberg SF: Signaling properties and functions of two distinct cardiomyocyte protease-activated receptors. Circ Res 2000;86:1054-1061.

31 Glembotski CC, Irons CE, Krown KA, Murray SF, Sprenkle AB, Sei CA: Myocardial alpha-thrombin receptor activation induces hypertrophy and increases atrial natriuretic factor gene expression. J Biol Chem 1993;268: 20646-20652.

32 Sabri A, Short J, Guo J, Steinberg SF: Proteaseactivated receptor-1-mediated DNA synthesis in cardiac fibroblast is via epidermal growth factor receptor transactivation: distinct PAR1 signaling pathways in cardiac fibroblasts and cardiomyocytes. Circ Res 2002;91:532-539.

33 Jaffre F, Friedman AE, Hu Z, Mackman N, Blaxall BC: Beta-adrenergic receptor stimulation transactivates protease-activated receptor 1 via matrix metalloproteinase 13 in cardiac cells. Circulation 2012;125:2993-3003.

34 Antoniak S, Owens AP 3rd, Baunacke M, Williams JC, Lee RD, Weithauser A, Sheridan PA, Malz R, Luyendyk JP, Esserman DA, Trejo J, Kirchhofer D, Blaxall BC, Pawlinski R, Beck MA, Rauch U, Mackman N: PAR-1 contributes to the innate immune response during viral infection. J Clin Invest 2013;123:1310-1322.

35 Antoniak S, Rojas M, Spring D, Bullard TA, Verrier ED, Blaxall BC, Mackman N, Pawlinski R: Protease-activated receptor 2 deficiency reduces cardiac ischemia/reperfusion injury. Arterioscler Thromb Vasc Biol 2010;30: 2136-2142.

36 Hathaway CK, Grant R, Hagaman JR, Hiller S, Li F, Xu L, Chang AS, Madden VJ, Bagnell CR, Rojas M, Kim HS, Wu B, Zhou B, Smithies O, Kakoki M: Endothelin-1 critically influences cardiac function via superoxide-MMP9 cascade. Proc Natl Acad Sci USA 2015;112: 5141-5146.

37 Antoniak S, Tatsumi K, Bode M, Vanja S, Williams JC, Mackman N: Protease-activated receptor-1 enhances poly I:C induction of the anti-viral response in macrophages and mice. J Innate Immun 2016, DOI: 10.1159/ 000450853.

38 Antoniak S, Sparkenbaugh EM, Tencati M, Rojas M, Mackman N, Pawlinski R: Protease activated receptor- 2 contributes to heart failure. PLoS One 2013;8:e81733.

39 Chrysohoou C, Pitsavos C, Panagiotakos DB, Skoumas J, Stefanadis C: Association between prehypertension status and inflammatory markers related to atherosclerotic disease: the ATTICA Study. Am J Hypertens 2004; 17: 568-573. 
40 Hein L: Genetic deletion and overexpression of angiotensin II receptors. J Mol Med (Berl) 1998;76:756-763.

41 Mikolajczyk TP, Nosalski R, Szczepaniak P, Budzyn K, Osmenda G, Skiba D, Sagan A, Wu J, Vinh A, Marvar PJ, Guzik B, Podolec J, Drummond G, Lob HE, Harrison DG, Guzik TJ: Role of chemokine RANTES in the regulation of perivascular inflammation, T-cell accumulation, and vascular dysfunction in hypertension. FASEB J 2016;30:1987-1999.

42 Constantinides C, Mean R, Janssen BJ: Effects of isoflurane anesthesia on the cardiovascular function of the C57BL/6 mouse. ILAR J 2011; 52:e21-e31.

43 Vasan RS, Larson MG, Leip EP, Kannel WB, Levy D: Assessment of frequency of progression to hypertension in non-hypertensive participants in the Framingham Heart Study: a cohort study. Lancet 2001;358:1682-1686.

44 Celik T, Yuksel UC, Demirkol S, Bugan B, Iyisoy A, Kabul HK, Kilic S, Fici F, Yaman H: Relationship between increased systemic inflammation and impaired aortic elasticity in young patients with prehypertension. Blood Press Monit 2011;16:55-61.

45 Ferreira AS: Immunity, inflammation, and prehypertension: in what order? J Clin Hypertens (Greenwich) 2015;17:775-776.

46 Takeuchi O, Akira S: Pattern recognition receptors and inflammation. Cell 2010;140: 805-820.

47 De Miguel C, Rudemiller NP, Abais JM, Mattson DL: Inflammation and hypertension: new understandings and potential therapeutic targets. Curr Hypertens Rep 2015; 17:507.

48 Kajstura J, Cigola E, Malhotra A, Li P, Cheng W, Meggs LG, Anversa P: Angiotensin II induces apoptosis of adult ventricular myocytes in vitro. J Mol Cell Cardiol 1997;29:859-870.

49 Singh MV, Cicha MZ, Meyerholz DK, Chapleau MW, Abboud FM: Dual activation of TRIF and MyD88 adaptor proteins by angiotensin II evokes opposing effects on pressure, cardiac hypertrophy, and inflammatory gene expression. Hypertension 2015;66:647-656.

50 Mauno V, Hannu K, Esko K: Proinflammation and hypertension: a population-based study. Mediators Inflamm 2008;2008:619704.

51 Sriramula S, Francis J: Tumor necrosis factoralpha is essential for angiotensin II-induced ventricular remodeling: role for oxidative stress. PLoS One 2015;10:e0138372.
52 Muller-Brunotte R, Kahan T, Lopez B, Edner M, Gonzalez A, Diez J, Malmqvist K: Myocardial fibrosis and diastolic dysfunction in patients with hypertension: results from the Swedish Irbesartan Left Ventricular Hypertrophy Investigation versus Atenolol (SILVHIA). J Hypertens 2007;25:1958-1966.

53 Lijnen PJ, Petrov VV, Fagard RH: Association between transforming growth factor-beta and hypertension. Am J Hypertens 2003;16:604611.

54 Rosin NL, Falkenham A, Sopel MJ, Lee TD, Legare JF: Regulation and role of connective tissue growth factor in AngII-induced myocardial fibrosis. Am J Pathol 2013;182:714726.

55 Chen MM, Lam A, Abraham JA, Schreiner GF, Joly AH: CTGF expression is induced by TGF-beta in cardiac fibroblasts and cardiac myocytes: a potential role in heart fibrosis. J Mol Cell Cardiol 2000;32:1805-1819.

56 Villarreal FJ, Dillmann WH: Cardiac hypertrophy-induced changes in mRNA levels for TGF-beta 1, fibronectin, and collagen. Am J Physiol 1992;262:H1861-H1866.

57 Chambers RC, Leoni P, Blanc-Brude OP, Wembridge DE, Laurent GJ: Thrombin is a potent inducer of connective tissue growth factor production via proteolytic activation of protease-activated receptor-1. J Biol Chem 2000;275:35584-35591.

58 Celik T, Iyisoy A, Kursaklioglu H, Turhan H, Cagdas Yuksel U, Kilic S, Kutsi Kabul H, Genc C: Impaired aortic elastic properties in young patients with prehypertension. Blood Press Monit 2006;11:251-255.

59 Laine H, Raitakari OT, Niinikoski H, Pitkanen OP, Iida H, Viikari J, Nuutila P, Knuuti J: Early impairment of coronary flow reserve in young men with borderline hypertension. J Am Coll Cardiol 1998;32:147-153.

60 Erdogan D, Yildirim I, Ciftci O, Ozer I, Caliskan M, Gullu H, Muderrisoglu H: Effects of normal blood pressure, prehypertension, and hypertension on coronary microvascular function. Circulation 2007;115:593-599.

61 Di Bello V, Talini E, Dell'Omo G, Giannini C Delle Donne MG, Canale ML, Nardi C, Palagi C, Dini FL, Penno G, Del Prato S, Marzilli M, Pedrinelli R: Early left ventricular mechanics abnormalities in prehypertension: a two-dimensional strain echocardiography study. Am J Hypertens 2010;23:405-412.
62 de Gasparo M, Catt KJ, Inagami T, Wright JW, Unger T: International union of pharmacology. 23. The angiotensin II receptors. Pharmacol Rev 2000;52:415-472.

63 Chae CU, Lee RT, Rifai N, Ridker PM: Blood pressure and inflammation in apparently healthy men. Hypertension 2001;38:399-403.

64 Weber T, Auer J, O’Rourke MF, Kvas E, Lassnig E, Berent R, Eber B: Arterial stiffness, wave reflections, and the risk of coronary artery disease. Circulation 2004;109:184-189.

65 Nugent WH, Mishra N, Strauss JF 3rd, Walsh SW: Matrix metalloproteinase 1 causes vasoconstriction and enhances vessel reactivity to angiotensin II via protease-activated receptor 1. Reprod Sci 2016;23:542-548.

66 Cheng C, Tempel D, van Haperen R, van Damme L, Algur M, Krams R, de Crom R: Activation of MMP8 and MMP13 by angiotensin II correlates to severe intra-plaque hemorrhages and collagen breakdown in atherosclerotic lesions with a vulnerable phenotype. Atherosclerosis 2009;204:26-33.

67 Wang S, Reeves B, Sparkenbaugh EM, Russell J, Soltys Z, Zhang H, Faber JE, Key NS, Kirchhofer D, Granger DN, Mackman N, Pawlinski R: Protective and detrimental effects of neuroectodermal cell-derived tissue factor in mouse models of stroke. JCI Insight 2016;1: e86663.

68 Pawlinski R, Fernandes A, Kehrle B, Pedersen B, Parry G, Erlich J, Pyo R, Gutstein D, Zhang J, Castellino F, Melis E, Carmeliet P, Baretton G, Luther T, Taubman M, Rosen E, Mackman $\mathrm{N}$ : Tissue factor deficiency causes cardiac fibrosis and left ventricular dysfunction. Proc Natl Acad Sci USA 2002;99:15333-15338.

69 Erlich JH, Boyle EM, Labriola J, Kovacich JC, Santucci RA, Fearns C, Morgan EN, Yun W, Luther T, Kojikawa O, Martin TR, Pohlman $\mathrm{TH}$, Verrier ED, Mackman N: Inhibition of the tissue factor-thrombin pathway limits infarct size after myocardial ischemia-reperfusion injury by reducing inflammation. Am J Pathol 2000;157:1849-1862.

70 Bode MF, Mackman N: Protective and pathological roles of tissue factor in the heart. Hamostaseologie 2015;35:37-46.

71 Antoniak S, Tatsumi K, Hisada Y, Milner JJ, Neidich SD, Shaver CM, Pawlinski R, Beck MA, Bastarache JA, Mackman N: Tissue factor deficiency increases alveolar hemorrhage and death in influenza A virus-infected mice. J Thromb Haemost 2016;14:1238-1248. 